\title{
Determinants of e-Commerce Use at Different Educational Levels: Empirical Evidence from Turkey

\author{
e-Commerce Use at Different Educational Levels
}

\author{
Şeyda Ünver ${ }^{1}$ \\ Research Assistant, Department of Econometrics \\ Ataturk University, Erzurum, Turkey
}

\author{
Ömer Alkan ${ }^{2}$ \\ Associate Professor, Department of Econometrics \\ Ataturk University, Erzurum, Turkey
}

\begin{abstract}
Rapid spread of internet has made e-commerce an essential and effective tool for commercial transactions. The purpose of this study is to investigate e-commerce use differences between individuals in Turkey according to their educational levels and to specify the relationship between demographic characteristics of individuals and e-commerce use. In this study, the cross-sectional data obtained by Household Information Technologies Usage Survey were used. Binary logistic regression analysis was utilized to determine the factors associated with the e-commerce use of individuals. This study has concluded that the variables of income level, age, gender, occupation, region, social media use, use of internet banking, use of e-government, number of information equipment in a household and the number of people in a household have relationships with e-commerce use. In addition, it has been found out that the variables in e-commerce use showed differences according to educational levels of individuals. It has been determined as a result of this study that as the education level of the individuals increased, their tendency towards online shopping increased. Higher education level refers to higher income level at both state and private institutions and more perception towards innovations. This has naturally a positive effect on online shopping behaviors of individuals.
\end{abstract}

Keywords-Electronic commerce; online shopping; educational level; e-commerce; Turkey; binary logistic regression

\section{INTRODUCTION}

Significant developments are observed in commercial issues due to the significant increase in the impact of information technologies on our lives. There are new electronic commerce opportunities for purchasers (customers or enterprises). Electronic commerce refers to internet-based sales [1]. It is usually abbreviated as e-commerce or e-Commerce [2]. e-Commerce first started in 1994, and has aroused the interest of many retailers and traders due to the advantages it offers for both companies and consumers [3]. The rapid spread of internet has made e-commerce an essential and effective tool for commercial transactions [4].

e-Commerce may be defined as the use of electronic networked computer-based technologies to place new products, services and ideas on the market, to support and develop business operations [1]. e-Commerce benefits from the technologies, such as mobile commerce, electronic fund transfer, supply chain management, internet marketing, online transaction processing, electronic data interchange, inventory management systems and automated data collection systems.
Modern electronic commerce generally uses World Wide Web during at least one part of a transaction's life cycle in addition to other technologies, such as e-mail [5]. Today, e-commerce is used as a quick tool to transform the world into an information society [6].

In online shopping, consumers can do shopping 24 hours a day and are not required to visit any physical store of sellers, located in another city or country [7]. In addition, online shopping provides consumers with more control and bargaining power when compared with traditional shopping as it is possible to obtain more information about products and services available on the internet [2].

Turkey is a country with a significant growth potential in ecommerce, having increasing number of e-sellers and a large, young population. e-Commerce started to be carried out significantly in Turkey as of 1990s, and has been in a rapid increase as of early 2000s [8]. Turkish Informatics Industry Association stated that e-commerce increased by $42 \%$ in Turkey in 2018 [9].

It is seen that individuals use e-commerce in several different manners and for various purposes [10, 11]. As ecommerce use improves opportunities in many areas, it is of importance to evaluate the scopes of differences and underlying causes [12]. It is known that the demographic characteristics of individuals affect their actions before they display any behavior [13]. Therefore, the differences in ecommerce use in various respects between demographic groups is an interesting research topic [14]. In the literature, there are studies showing that demographic factors affect individuals' attitudes towards online purchasing behavior [15-18]. Distribution of different demographic groups is of importance to analyze e-commerce use according to educational levels of individuals. In this study, a systematic analysis was carried out to investigate the effect of selected demographic factors on ecommerce use among individuals according to their education levels.

In Turkey, there is not sufficient information on educational level differences of individuals regarding e-commerce use. As far as we know, this is the first study conducted to determine the e-commerce related factors according to educational levels of individuals across Turkey. In this study, the following research questions were developed regarding the e-commerce use of individuals in Turkey according to their educational 
levels: "Does e-commerce use differs according to the education levels of individuals?", "Is there a relationship between individuals' demographic characteristics and ecommerce use?" and "Are the factors related to the use of ecommerce by individuals with different education levels the same?”.

\section{LITERATURE REVIEW}

In the early studies on e-commerce, it was investigated how e-commerce influenced price levels and price range [19]. In these studies, it was concluded that online markets did not offer lower prices than traditional markets [20]. However, the conclusions achieved in the following studies urged that online markets referred to a tendency of lower price ranges than traditional markets [19].

In e-commerce platforms, extensive investigations were conducted by academics to learn about e-commerce adoption behaviors. It was tried to provide information on e-commerce adoption behaviors from various perspectives, such as individual consumers and enterprises or organizations [21]. Of these studies, those subjecting individual consumers examined the commercial features of Internet and how it would affect consumer adoption of B2C (manufacturer-to-consumer) ecommerce [22-24]. In addition, some studies implemented the elaboration likelihood model (ELM) and the technology acceptance model (TAM) to discover the factors leading consumers to purchase food through e-commerce platforms [25-27]. Another study investigated the basic factors of ecommerce adoption wish from the perspectives of farmers [28].

The studies on adoption behaviors of e-commerce from the perspectives of enterprises and organizations were also examined. It was seen that a study compared the theory of planned behavior (TPB) and theory of reasoned action (TRA) by using a structural equation model, which was developed to predict whether small-sized enterprises or medium-sized enterprises (SMEs) were more willing in the adoption of ecommerce [29]. In another study, the factors affecting ecommerce adoption by Malaysian SMEs in terms of relative advantage and competitive pressure were examined [30]. In addition, while a recent study has investigated the obstacles before the adoption of mobile commerce (m-commerce) by SMEs in the United Kingdom [31], another study has examined the basic factors in the adoption of m-commerce by SMEs in Vietnam [32]. Another study conducted in China investigated the main factors affecting consumers' willingness and behaviors to adopt e-commerce as well as willingnessbehavior consistency [21].

In e-commerce literature, there are also studies used logit and probit models. For example, a study on the comparison of e-commerce strategies between males and females used logit and probit models [33]. Moreover, probit models were also used in the studies on the adoption of e-commerce [34, 35]. In a study conducted in Iran's Kermanshah province, nonlinear logit and probit models were used to analyze the important factors affecting the tendency of small and medium enterprises (SMEs) to use electronic commerce [36].

In the studies conducted in recent years in Turkey, the factors effective on individuals' online purchasing behaviors have been identified [2, 3, 37-39]. In addition, these studies have subjected the issues such as e-satisfaction, e-loyalty and e-service quality regarding e-commerce [8, 40, 41]. In a study discussing the relationship between e-commerce and business logistics, e-commerce use in Turkey and Croatia was analyzed and the importance of business logistics was underlined for the development of e-commerce [1].

\section{MATERIALS AND METHODS}

\section{A. Data}

In this study, Household Information Technologies (IT) Usage Survey performed by the Turkish Statistical Institute in 2019 was used as micro data set. Household Information Technologies Usage Survey, which is carried out since 2004, aims to collect information about information and communication technologies owned by households and individuals and their uses.

In the Household Information Technologies Usage Survey, all residential areas across Turkey were included for sample selection. This study covers all households in all residential areas within the borders of Turkey. This study does not include those living in schools, dormitories, hotels, kindergartens, old age asylums, hospitals and prisons, which are defined as institutional population, and those staying in barracks and army houses. In addition, residential areas that were not considered to reach a sufficient number of sample households (small villages, large nomad tents, hamlet, etc.) with a population not exceeding $1 \%$ of the total population were excluded. The study covers the individuals between the age range of 16-74.

Two-stage stratified cluster sampling method was used for sampling. In the first stage, clusters (blocks) with an average of 100 households were selected as sample by proportional probability (PPS). In the second stage, sample addresses from the clusters selected for the sample were determined using the systematic selection method. Statistical Territorial Units Classification was used as the $1^{\text {st }}$ Level stratification criterion [42].

In this study, 18031 of the individuals participated in Household Information Technologies Usage Survey in 2019 have an elementary and lower degree graduation, 5552 of them are high school graduated and 5092 of them have a university degree.

\section{B. Measures and Variables}

In The dependent variable of this study is the commerce use status of individuals in the recent year according to their educational levels (elementary and lower, high school and university). The individuals participating in the research received the code "1" if used e-commerce within the recent year as of the period of the survey, and "0" if they did not. In this study, a separate binary logit model was established for each educational level.

Categorical variables included in the model were measured by a nominal and ordinal scale. The independent variables were specified as follows: income level (£2000 and below, $€ 2001-€ 4000$, 25-34, 35-44, 45-54, 55-64 and 65, and above), gender (male, female), occupation (unemployed individuals, managers, 
professionals, technicians and associate professionals, clerical support workers, service/sales workers, skilled agricultural/forestry/fishery workers, craft/related trades workers, plant-machine operators/assemblers, elementary occupations), use of social media in the recent three months (yes, no), use of internet banking (yes, no), use of egovernment in the last 12 months (yes, no), the number of information equipment in the household (1 and above, 2-3, 4 and above), the number of individuals in the household ( 3 and less, 4-5, 6 and above). Another independent variable is region. Turkey was classified into 12 regions in Level 1 under Nomenclature of Territorial Units for Statistics (NUTS). We classified these 12 regions as west, middle and east in this study. These regions and the provinces in these regions are shown in detail in Table I [43].
Ordinal and nominal variables were identified as dummy variables in order to observe the effects of the categories of all variables to be included in binary logistic regression [44].

\section{Analysis Technique/Method}

SPSS 20 and Stata 15 programs were used to analyze the data. First of all, e-commerce use status of individuals participating in the study and frequency and percentages of independent variables were obtained. In this study, binary logistic regression method was utilized to investigate the differences between e-commerce use according to education levels. Binary logistic regression is a statistical analysis method used for the examination of a relationship between dependent variables and independent variable(s) in the event that dependent variable has two categories [45].

TABLE I. NOMENCLATURE OF TERRITORIAL UNITS FOR STATISTICS - LEVEL 1

\begin{tabular}{|c|c|c|c|}
\hline Region & Code & Level 1 & Provinces \\
\hline \multirow{4}{*}{$\begin{array}{l}\text { Western } \\
\text { Region }\end{array}$} & TR1 & İstanbul & İstanbul \\
\hline & TR2 & West Marmara & Tekirdağ, Edirne, Kırklareli, Balıkesir, Çanakkale \\
\hline & TR3 & Aegean & İzmir, Aydın, Denizli, Muğla, Manisa, Afyonkarahisar, Kütahya, Uşak \\
\hline & TR4 & East Marmara & Bursa, Eskişehir, Bilecik, Kocaeli, Sakarya, Düzce, Bolu, Yalova \\
\hline \multirow{4}{*}{$\begin{array}{l}\text { Central } \\
\text { Region }\end{array}$} & TR5 & West Anatolia & Ankara, Konya, Karaman \\
\hline & TR6 & Mediterranean & Antalya, Isparta, Burdur, Adana, Mersin, Hatay, Kahramanmaraş, Osmaniye \\
\hline & TR7 & Central Anatolia & Kırıkkale, Aksaray, Niğde, Nevşehir, Kırşehir, Kayseri, Sivas, Yozgat \\
\hline & TR8 & West Black Sea & Zonguldak, Karabük, Bartın, Kastamonu, Çankırı, Sinop, Samsun, Tokat, Çorum, Amasya \\
\hline \multirow{4}{*}{$\begin{array}{l}\text { Eastern } \\
\text { Region }\end{array}$} & TR9 & East Black Sea & Trabzon, Ordu, Giresun, Rize, Artvin, Gümüşhane \\
\hline & TRA & Northeast Anatolia & Erzurum, Erzincan, Bayburt, Ağrı, Kars, Iğdır, Ardahan \\
\hline & TRB & Centraleast Anatolia & Malatya, Elâzı ̆̆, Bingöl, Tunceli, Van, Muş, Bitlis, Hakkâri \\
\hline & TRC & Southeast Anatolia & Gaziantep, Adıyaman, Kilis, Şanlıurfa, Diyarbakır, Mardin, Batman, Şırnak, Siirt \\
\hline
\end{tabular}

\section{RESULTS}

\section{A. Descriptive Statistics}

As of the date when this questionnaire was administered, it was identified that $12.45 \%$ of the individuals with an elementary and lower graduation, $45.57 \%$ of the individuals graduated from high school and $71.11 \%$ of the individuals with a university degree did a shopping on internet in the recent year.

The results of the factors that are associated with ecommerce use according to educational levels of individuals in Turkey are shown in Table II.

\section{B. Model Estimation}

The results of estimated binary logistic regression model are provided in Table III. In this study, it was tested whether there was any multicollinearity among the independent variables to be included in the binary logistic regression model. It is considered that those with variance inflation factor (VIF) values of 5 and above cause moderate, and those with 10 and above variance inflation factor (VIF) values cause a high degree multicollinearity [46]. In this study, there was not any variable causing any multicollinearity problem among the variables.
In Table III, the binary logistic regression models estimated for individuals with an elementary and lower graduation, graduated from high school and with a university degree are shown.

The marginal effects of the factors associated with ecommerce use of individuals according to their education levels are given in Table IV.

For individuals with an elementary and lower graduation, the likelihood of an individual with an income of $¥ 6001$ and above to use e-commerce is $57.9 \%$ more than an individual with an income of $€ 2000$ and lower (reference group). The likelihood of a 25-34 years old individual with an elementary and lower graduation to use e-commerce is $32.2 \%$ less than a 15-24 years old individual. The likelihood of a 45-54 years old individual with an elementary and lower graduation to use ecommerce is $119.3 \%$ less than a $15-24$ years old individual. The likelihood of a female with an elementary and lower graduation to use e-commerce is $38.2 \%$ less than a male having the same education level. The likelihood of an individual with an elementary and lower graduation in the middle region to use e-commerce is $39.9 \%$ more than an individual in the east region. An individual with an elementary and lower graduation as well as a member of a professional occupation is $148.7 \%$ more likely to use e-commerce than a unemployed individual. 
The likelihood of an individual with an elementary and lower graduation as well as a skilled agricultural/forestry/fishery workers to use e-commerce is $71.6 \%$ less than a unemployed individual. The likelihood of an individual with an elementary education and lower graduation in households with 1 or less information equipment is $75.2 \%$ less than an individual in a household with 4 or more information equipment. An individual with an elementary and lower graduation in a household with 6 and above individuals is $40.9 \%$ less likely to use e-commerce than an individual in a household with 3 and lower individuals. The likelihood of an individual with an elementary and lower graduation as well as a using social media to use e-commerce is $123.4 \%$ higher than an individual not using social media. An individual with an elementary and lower graduation as well as a using internet banking is $106.5 \%$ more likely to use e-commerce than an individual not using internet banking. The likelihood of an individual with an elementary and lower graduation as well as a using egovernment to use e-commerce is $79 \%$ higher than an individual not using this application.

TABLE II. FINDINGS OF THE FACTORS AFFECTING E-COMMERCE USE OF INDIVIDUALS ACCORDING TO THEIR EDUCATIONAL LEVELS

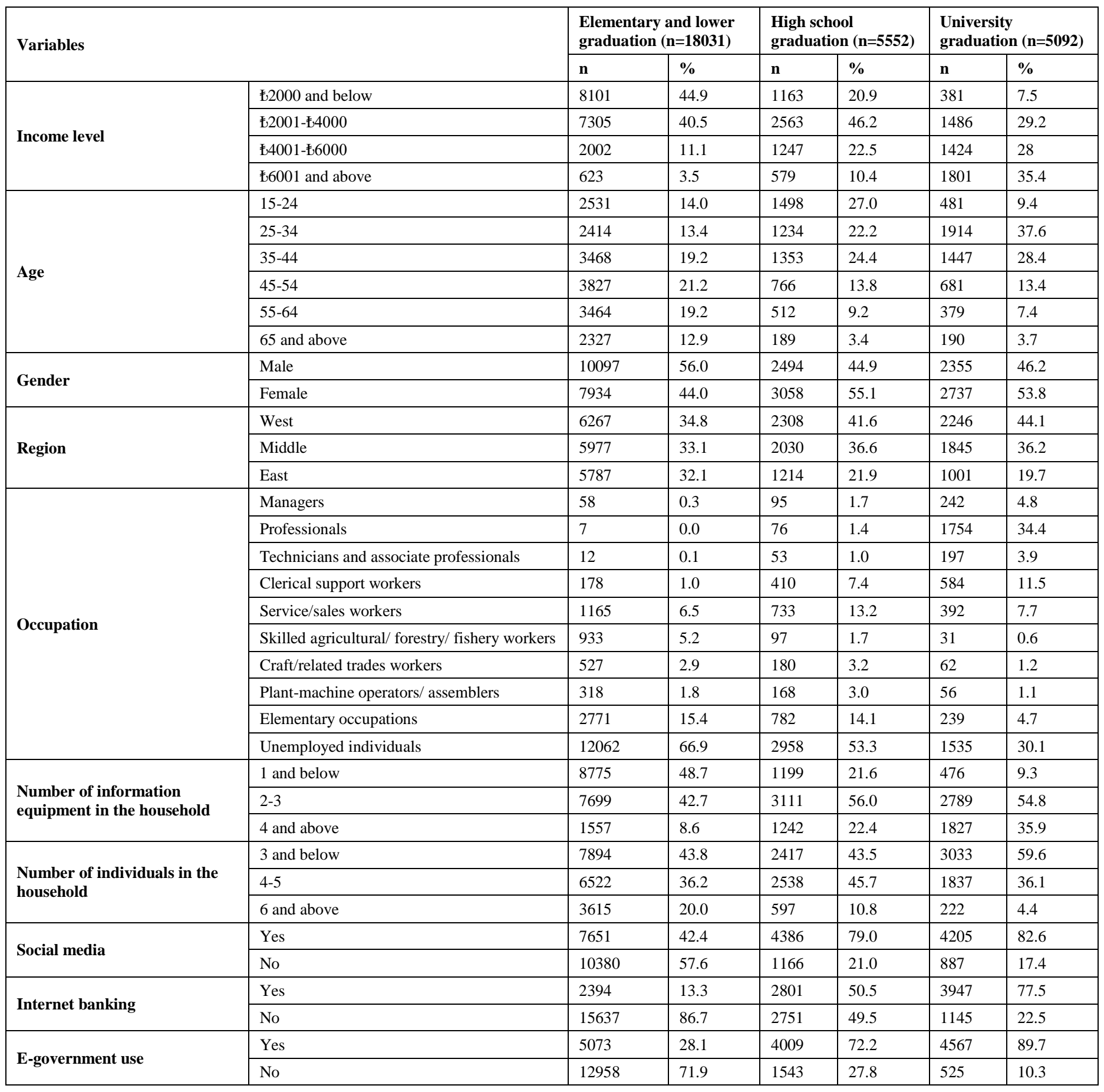


TABLE III. ESTIMATED MODEL RESULTS FOR THE FACTORS ASSOCIATED WITH E-COMMERCE USE OF INDIVIDUALS BY EDUCATION LEVELS

\begin{tabular}{|c|c|c|c|c|c|c|}
\hline \multirow{2}{*}{ Variables } & \multicolumn{2}{|c|}{$\begin{array}{l}\text { Elementary and lower } \\
\text { graduation }\end{array}$} & \multicolumn{2}{|c|}{ High school graduation } & \multicolumn{2}{|c|}{ University graduation } \\
\hline & $\boldsymbol{\beta}$ & SE & $\boldsymbol{\beta}$ & SE & $\boldsymbol{\beta}$ & SE \\
\hline Constant & $-2.377^{\mathrm{a}}$ & 0.172 & $-1.148^{\mathrm{a}}$ & 0.193 & $-1.397^{\mathrm{a}}$ & 0.275 \\
\hline \multicolumn{7}{|c|}{ Income level (reference category: $€ 2000$ and below) } \\
\hline$€ 2001-€ 4000$ & $0.281^{\mathrm{a}}$ & 0.08 & 0.11 & 0.101 & $0.451^{\mathrm{a}}$ & 0.159 \\
\hline$€ 4001-€ 6000$ & $0.280^{\mathrm{a}}$ & 0.108 & $0.26^{\mathrm{b}}$ & 0.118 & $0.611^{\mathrm{a}}$ & 0.168 \\
\hline$€ 6001$ and above & $0.668^{\mathrm{a}}$ & 0.149 & $0.523^{\mathrm{a}}$ & 0.148 & $0.826^{\mathrm{a}}$ & 0.173 \\
\hline \multicolumn{7}{|l|}{ Age (reference category: 15-24) } \\
\hline 25-34 & $-0.399^{\mathrm{a}}$ & 0.093 & $-0.421^{\mathrm{a}}$ & 0.106 & -0.007 & 0.152 \\
\hline $35-44$ & $-1.059^{\mathrm{a}}$ & 0.097 & $-0.832^{\mathrm{a}}$ & 0.107 & $-0.424^{\mathrm{a}}$ & 0.159 \\
\hline $45-54$ & $-1.719^{\mathrm{a}}$ & 0.111 & $-1.604^{\mathrm{a}}$ & 0.127 & $-1.188^{\mathrm{a}}$ & 0.173 \\
\hline $55-64$ & $-2.718^{\mathrm{a}}$ & 0.177 & $-2.222^{\mathrm{a}}$ & 0.176 & $-1.754^{\mathrm{a}}$ & 0.205 \\
\hline 65 and above & $-2.399^{\mathrm{a}}$ & 0.239 & $-2.673^{\mathrm{a}}$ & 0.324 & $-2.342^{\mathrm{a}}$ & 0.306 \\
\hline \multicolumn{7}{|l|}{ Gender (reference category: male) } \\
\hline Female & $-0.437^{\mathrm{a}}$ & 0.08 & $-0.281^{\mathrm{a}}$ & 0.085 & $-0.179^{\mathrm{b}}$ & 0.091 \\
\hline \multicolumn{7}{|l|}{ Region (reference category: east) } \\
\hline West & $0.416^{\mathrm{a}}$ & 0.098 & $0.278^{b}$ & 0.112 & $0.33^{\mathrm{a}}$ & 0.118 \\
\hline Middle & $0.451^{\mathrm{a}}$ & 0.098 & 0.146 & 0.11 & $0.33^{\mathrm{a}}$ & 0.117 \\
\hline \multicolumn{7}{|c|}{ Occupation (reference category: unemployed individuals) } \\
\hline Managers & 0.637 & 0.397 & $0.517^{c}$ & 0.29 & $0.591^{\mathrm{b}}$ & 0.234 \\
\hline Professionals & $1.934^{\mathrm{a}}$ & 0.6 & -0.094 & 0.273 & 0.164 & 0.12 \\
\hline Technicians and associate professionals & 0.475 & 0.674 & $0.721^{\mathrm{c}}$ & 0.393 & 0.113 & 0.236 \\
\hline Clerical support workers & $0.382^{c}$ & 0.227 & 0.207 & 0.157 & 0.084 & 0.152 \\
\hline Service/sales workers & -0.019 & 0.12 & 0.067 & 0.12 & -0.095 & 0.169 \\
\hline Skilled agricultural/ forestry/ fishery workers & $-0.801^{\mathrm{a}}$ & 0.287 & $-0.863^{\mathrm{b}}$ & 0.364 & -0.56 & 0.386 \\
\hline Craft/related trades workers & $-0.471^{\text {a }}$ & 0.163 & -0.142 & 0.213 & -0.157 & 0.389 \\
\hline Plant-machine operators/ assemblers & $-0.480^{\mathrm{b}}$ & 0.2 & $-0.382^{c}$ & 0.208 & $-0.915^{\mathrm{b}}$ & 0.362 \\
\hline Elementary occupations & $-0.451^{\mathrm{a}}$ & 0.104 & $-0.245^{\mathrm{b}}$ & 0.123 & $-0.635^{\mathrm{a}}$ & 0.196 \\
\hline \multicolumn{7}{|c|}{ Number of information equipment in the household (reference category: 4 and above) } \\
\hline 1 and below & $-0.858^{\mathrm{a}}$ & 0.111 & $-0.896^{\mathrm{a}}$ & 0.125 & $-0.989^{\mathrm{a}}$ & 0.158 \\
\hline $2-3$ & $-0.303^{\mathrm{a}}$ & 0.092 & $-0.34^{\mathrm{a}}$ & 0.091 & $-0.506^{\mathrm{a}}$ & 0.092 \\
\hline \multicolumn{7}{|c|}{ Number of individuals in the household (reference category: 3 and below) } \\
\hline $4-5$ & $-0.173^{\mathrm{b}}$ & 0.074 & $-0.326^{\mathrm{a}}$ & 0.08 & $-0.18^{\mathrm{b}}$ & 0.089 \\
\hline 6 and above & $-0.465^{\mathrm{a}}$ & 0.107 & $-0.5^{\mathrm{a}}$ & 0.136 & $-0.489^{b}$ & 0.202 \\
\hline \multicolumn{7}{|l|}{ Social media (reference category: no) } \\
\hline Yes & $1.366^{\mathrm{a}}$ & 0.106 & $0.653^{\mathrm{a}}$ & 0.103 & $0.525^{\mathrm{a}}$ & 0.106 \\
\hline \multicolumn{7}{|l|}{ Internet banking (reference category: no) } \\
\hline Yes & $1.246^{\mathrm{a}}$ & 0.085 & $1.342^{\mathrm{a}}$ & 0.86 & $1.465^{\mathrm{a}}$ & 0.103 \\
\hline \multicolumn{7}{|l|}{ E-government use (reference category: no) } \\
\hline Yes & $-2.377^{\mathrm{a}}$ & 0.172 & $0.93^{\mathrm{a}}$ & 0.105 & $1.017^{\mathrm{a}}$ & 0.141 \\
\hline
\end{tabular}


TABLE IV. MARGINAL EFFECTS OF FACTORs AsSOCIATED WITH INDIVIDUALS' USE OF E-COMMERCE By EdUCATION LEVEL

\begin{tabular}{|c|c|c|c|c|c|c|}
\hline \multirow{2}{*}{ Variables } & \multicolumn{2}{|c|}{$\begin{array}{l}\text { Elementary and lower } \\
\text { graduation }\end{array}$} & \multicolumn{2}{|c|}{$\begin{array}{l}\text { High school } \\
\text { graduation }\end{array}$} & \multicolumn{2}{|c|}{$\begin{array}{l}\text { University } \\
\text { graduation }\end{array}$} \\
\hline & ME & S.E & ME & S.E & ME & S.E \\
\hline \multicolumn{7}{|c|}{ Income level (reference category: $\mathbf{1 2 0 0 0}$ and below) } \\
\hline$€ 2001-€ 4000$ & $0.248^{\mathrm{a}}$ & 0.705 & 0.062 & 0.057 & $0.156^{\mathrm{a}}$ & 0.059 \\
\hline$€ 4001-€ 6000$ & $0.247^{\mathrm{b}}$ & 0.952 & $0.143^{\mathrm{b}}$ & 0.066 & $0.203^{\mathrm{a}}$ & 0.061 \\
\hline$€ 6001$ and above & $0.579^{\mathrm{a}}$ & 0.126 & $0.277^{\mathrm{a}}$ & 0.077 & $0.26^{\mathrm{a}}$ & 0.061 \\
\hline \multicolumn{7}{|l|}{ Age (reference category: 15-24) } \\
\hline $25-34$ & $-0.322^{\mathrm{a}}$ & 0.075 & $-0.193^{\mathrm{a}}$ & 0.049 & -0.002 & 0.034 \\
\hline $35-44$ & $-0.891^{\mathrm{a}}$ & 0.081 & $-0.415^{\mathrm{a}}$ & 0.054 & $-0.108^{\mathrm{a}}$ & 0.038 \\
\hline $45-54$ & $-1.493^{\mathrm{a}}$ & 0.098 & $-0.914^{\mathrm{a}}$ & 0.08 & $-0.377^{\mathrm{a}}$ & 0.053 \\
\hline $55-64$ & $-2.448^{\mathrm{a}}$ & 0.167 & $-1.386^{\mathrm{a}}$ & 0.133 & $-0.647^{\mathrm{a}}$ & 0.085 \\
\hline 65 and above & $-2.139^{\mathrm{a}}$ & 0.226 & $-1.763^{\mathrm{a}}$ & 0.275 & $-0.997^{\mathrm{a}}$ & 0.18 \\
\hline \multicolumn{7}{|l|}{ Gender (reference category: male) } \\
\hline Female & $-0.382^{\mathrm{a}}$ & 0.069 & $-0.152^{\mathrm{a}}$ & 0.046 & $-0.051^{\mathrm{b}}$ & 0.026 \\
\hline \multicolumn{7}{|l|}{ Region (reference category: east) } \\
\hline West & $0.369^{\mathrm{a}}$ & 0.088 & $0.154^{\mathrm{b}}$ & 0.063 & $0.101^{\mathrm{a}}$ & 0.038 \\
\hline Middle & $0.399^{\mathrm{a}}$ & 0.087 & 0.082 & 0.063 & $0.102^{\mathrm{a}}$ & 0.037 \\
\hline \multicolumn{7}{|c|}{ Occupation (reference category: unemployed individuals) } \\
\hline Managers & $0.533^{\mathrm{c}}$ & 0.321 & $0.256^{\mathrm{c}}$ & 0.132 & $0.148^{\mathrm{a}}$ & 0.053 \\
\hline Professionals & $1.487^{\mathrm{a}}$ & 0.435 & -0.052 & 0.152 & 0.046 & 0.034 \\
\hline Technicians and associate professionals & 0.401 & 0.555 & $0.344^{\mathrm{b}}$ & 0.164 & 0.032 & 0.066 \\
\hline Clerical support workers & $0.324^{\mathrm{c}}$ & 0.189 & 0.108 & 0.08 & 0.024 & 0.043 \\
\hline Service/sales workers & -0.016 & 0.104 & 0.036 & 0.064 & -0.029 & 0.051 \\
\hline Skilled agricultural/ forestry/ fishery workers & $-0.716^{\mathrm{a}}$ & 0.264 & $-0.531^{b}$ & 0.25 & -0.189 & 0.147 \\
\hline Craft/related trades workers & $-0.416^{\mathrm{a}}$ & 0.146 & -0.079 & 0.12 & -0.048 & 0.123 \\
\hline Plant-machine operators/ assemblers & $-0.424^{b}$ & 0.179 & $-0.219^{c}$ & 0.125 & $-0.337^{b}$ & 0.16 \\
\hline Elementary occupations & $-0.398^{\mathrm{a}}$ & 0.093 & $-0.137^{\mathrm{c}}$ & 0.07 & $-0.218^{\mathrm{a}}$ & 0.075 \\
\hline \multicolumn{7}{|c|}{ Number of information equipment in the household (reference category: 4 and above) } \\
\hline 1 and below & $-0.752^{\mathrm{a}}$ & 0.096 & $-0.502^{\mathrm{a}}$ & 0.072 & $-0.305^{\mathrm{a}}$ & 0.057 \\
\hline $2-3$ & $-0.258^{\mathrm{a}}$ & 0.078 & $-0.174^{\mathrm{a}}$ & 0.045 & $-0.137^{\mathrm{a}}$ & 0.024 \\
\hline \multicolumn{7}{|c|}{ Number of individuals in the household (reference category: 3 and below) } \\
\hline 4-5 & $-0.15^{\mathrm{b}}$ & 0.064 & $-0.174^{\mathrm{a}}$ & 0.042 & $-0.052^{\mathrm{b}}$ & 0.026 \\
\hline 6 and above & $-0.409^{\mathrm{a}}$ & 0.095 & $-0.274^{\mathrm{a}}$ & 0.078 & $-0.152^{\mathrm{b}}$ & 0.069 \\
\hline \multicolumn{7}{|l|}{ Social media (reference category: no) } \\
\hline Yes & $1.234^{\mathrm{a}}$ & 0.099 & $0.384^{\mathrm{a}}$ & 0.06 & $0.166^{\mathrm{a}}$ & 0.037 \\
\hline \multicolumn{7}{|l|}{ Internet banking (reference category: no) } \\
\hline Yes & $1.065^{\mathrm{a}}$ & 0.071 & $0.76^{\mathrm{a}}$ & 0.051 & $0.53^{\mathrm{a}}$ & 0.046 \\
\hline \multicolumn{7}{|l|}{ E-government use (reference category: no) } \\
\hline Yes & $0.790^{\mathrm{a}}$ & 0.071 & $0.557^{\mathrm{a}}$ & 0.069 & $0.366^{\mathrm{a}}$ & 0.062 \\
\hline
\end{tabular}


For individuals with high school graduation, the likelihood of an individual with an income of $€ 6001$ and above to use ecommerce is $27.7 \%$ more than an individual with an income of €2000 and lower (reference group). A 25-34 years old individual with a high school graduation is $19.3 \%$ less likely to use e-commerce than a 15-24 years old individual. The likelihood of an individual with high school graduation and in 65 and above age range to use e-commerce is $176.3 \%$ less than a 15-24 years old individual. A female with a high school graduation is $15.2 \%$ less likely to use e-commerce than a male with same degree graduation. The likelihood of an individual with a high school graduation in the west region to use ecommerce is $15.4 \%$ less than an individual in the east region. The likelihood of an individual with a high school graduation as well as a technicians and associate professional to use ecommerce is $34.4 \%$ more than a unemployed individual. The likelihood of an individual with a high school graduation as well as a skilled agricultural/forestry/fishery workers to use ecommerce is $53.1 \%$ less than a unemployed individual. The likelihood of an individual with a high school graduation in households with 1 or less information equipment is $50.2 \%$ less than an individual in a household with 4 or more information equipment. An individual with a high school graduation in a household with 6 and above individuals is $27.4 \%$ less likely to use e-commerce than an individual in a household with 3 and lower individuals. The likelihood of an individual with a high school graduation as well as using social media to use ecommerce is $38.4 \%$ higher than an individual not using social media. An individual with a high school graduation as well as a using internet banking is $76 \%$ more likely to use e-commerce than an individual not using internet banking. The likelihood of an individual with a high school graduation as well as a using e-government to use e-commerce is $55.7 \%$ higher than an individual not using this application.

For individuals with a university degree graduation, the likelihood of an individual with an income of $€ 6001$ and above to use e-commerce is $26 \%$ more than an individual with an income of $€ 2000$ and lower (reference group). A 35-44 years old individual with a university degree graduation is $41.5 \%$ less likely to use e-commerce than a 15-24 years old individual. The likelihood of an individual with a university degree graduation and in 65 and above age range to use ecommerce is $99.7 \%$ less than a $15-24$ years old individual. A female with a university degree graduation is $5.1 \%$ less likely to use e-commerce than a male with the same degree graduation. The likelihood of an individual with a university degree graduation in the west region to use e-commerce is $10.1 \%$ less than an individual in the east region. The likelihood of an individual with a university degree graduation as well as a manager to use e-commerce is $14.8 \%$ more than a unemployed individual. The likelihood of an individual with a university degree graduation as well as a Plant-machine operators/assembler to use e-commerce is $33.7 \%$ less than a unemployed individual. The likelihood of an individual with a university degree graduation in households with 1 or less information equipment is $30.5 \%$ less than an individual in a household with 4 or more information equipment. An individual with a university degree graduation in a household with 6 and above individuals is 15.2\% less likely to use ecommerce than an individual in a household with 3 and lower individuals. The likelihood of an individual with a university degree graduation as well as using social media to use ecommerce is $16.6 \%$ less than an individual not using social media. An individual with a university degree graduation as well as a using internet banking is $53 \%$ more likely to use ecommerce than an individual not using internet banking. The likelihood of an individual with a university degree as well as a using e-government to use e-commerce is $36.6 \%$ higher than an individual not using this application.

\section{DisCUSSION}

The rapid growth of online shopping activities in recent years has required a careful description of the main factors affecting consumers' behavior and attitudes towards online shopping. Individuals use e-commerce in several different types and for various reasons. As it is known that demographic characteristics affect the actions of individuals before displaying a certain behavior, the differences regarding internet use among demographic groups in various aspects have become an interesting area of research. It is of importance that the factors related to online shopping should be understood both by e-commerce suppliers and online shoppers. Education is a significant factor affecting the decision-making process of a customer in online shopping, and the effect of education level on online consumption is getting more important.

In this study, the data regarding 28675 individuals participated in the Household Information Technologies Usage Survey performed by the Turkish Statistical Institute in 2019. In addition, the factors affecting e-commerce use of individuals in Turkey have been determined according to their education levels by utilizing binary logistic regression.

In this study, the variables of income level, age, gender, occupation, region, social media use, internet banking use, egovernment use, number of information equipment in a household and the number of people in a household have been found to be related to e-commerce use.

As the income levels of individuals increase, their likelihood to use e-commerce increases. Other studies have also reached similar conclusions $[47,48]$. It was reported in a study carried out in New Zealand that the higher an individual's income, the more s/he trusts sales on internet [49].

It has been concluded in the study that as the age of the individuals increase, their possibility of using e-commerce decrease. Parallel results have been found in different studies $[3,50]$. Age is one of the factors affecting the attitudes of individuals to use e-commerce, thus, different age groups may have different tendencies regarding e-commerce [51]. On the other hand, prior studies show that as the age of individuals increase, their likelihood to use e-commerce increases [52]. It has been found out in a study conducted in New Zealand that the time used by elders for e-commerce on internet is not less than the time spent by other age groups [49].

It has been achieved that the likelihood of males to use ecommerce is higher than females. Other studies have also arrived at similar conclusions [53, 54]. It has been reported in a study that males have significantly more internet knowledge, computer understanding and experience compared to females [10]. It has been stated in another study that females are more 
anxious and less self-confident than males about computer, internet use and e-commerce [55].

It has been also identified that the likelihood of the individuals living in the western region to use e-commerce has been more than the individuals living in middle and eastern regions. The digital divide between regions with different levels of development affects how telecommunications and other advanced technologies are used [56]. Socioeconomic factors influence the use of information and communication technologies, and cause regional differences [57]. Different regions have different infrastructures, economies and populations, and this leads an environmental diversification of the location [58]. Therefore, this affects the difference between the shopping made by individuals on internet according to regions [59].

It has been found out that the e-commerce use of the individuals using social media is more than the individuals not using social media. The individuals managing a social media account may involve in more purchasing transactions through online channels. Parallel results have been found in different studies [60-62].

e-Commerce use of the individuals using internet banking is more than other individuals. Other studies have also arrived at similar conclusions $[60,63]$. It has been reported in a study that increase in internet access and growth in internet banking have resulted in a significant increase in e-commerce use [60].

In the study, it has been concluded that the e-commerce use of the individuals using e-government services is more than other individuals. Parallel results have been found in different studies [37, 64].

The study also urges that as the number of information equipment increases, the possibility of using e-commerce increases. Other studies have also arrived at similar conclusion $[39,47,65]$. It has been found out in a study that the increase in telephone numbers in families has increased the likelihood of online shopping [65].

It has been concluded in the study that as the household size increases, the likelihood to use e-commerce decreases. Parallel results have been found in different studies [39]. The effect of number of children on e-commerce use has been identified to be negative, little but insignificant in a study [66]. On the other hand, there are also studies that the effect of the number of children is the positive way on e-commerce use [67].

It has been found out that the significance and effects of variables in e-commerce use show differences according to educational levels of individuals. It has been concluded that as the education level of individuals' increase, the possibility of using e-commerce increase. The customers with different educational levels have different expectations and perceived service quality value. Our results show that the higher the education level of individuals, the higher their tendency towards online shopping. Higher education level refers to higher income level at both state and private institutions and more perception towards innovations. This has naturally a positive effect on online shopping behaviors of individuals.

\section{ACKNOWLEDGMENT}

The authors would like to thank the Turkish Statistical Institute for the data. The views and opinions expressed in this manuscript are those of the authors only and do not necessarily represent the views, official policy, or position of the Turkish Statistical Institute.

\section{REFERENCES}

[1] Erceg, A. and Z. Kilic. Interconnection of e-commerce and logistics: examples from Croatia and Turkey. in Business Logistics in Modern Management. 2018. Osijek, Croatia: Boris Crnković, Dean of Faculty of Economics in Osijek.

[2] Huseynov, F. and S.Ö. Yıldırım, Internet users' attitudes toward businessto-consumer online shopping: A survey. Information Development, 2016. 32(3): p. 452-465.

[3] Akman, I. and M. Rehan, Online purchase behaviour among professionals: a socio-demographic perspective for Turkey. Economic Research-Ekonomska Istraživanja, 2014. 27(1): p. 689-699.

[4] Çelik, H.E. and V. Yilmaz, Extending the technology acceptance model for adoption of e-shopping by consumers in Turkey. Journal of Electronic Commerce Research, 2011. 12(2): p. 152-164.

[5] Gümüş, R. and A. Kısa. Analysis of usability of web sites in hospitals in Diyarbakır, Turkey. in 3rd International Conference on Education, Social Sciences and Humanities. 2016. İstanbul: Socioint 2016.

[6] Kawa, A. and W. Zdrenka, Conception of integrator in cross-border ecommerce. LogForum, 2016. 12(1): p. 63-73.

[7] Gökmen, A., Virtual business operations, e-commerce \& its significance and the case of Turkey: current situation and its potential. Electronic Commerce Research, 2012. 12(1): p. 31-51.

[8] Kaya, B., et al., The moderating role of website familiarity in the relationships between e-service quality, e-satisfaction and e-loyalty. Journal of Internet Commerce, 2019. 18(4): p. 369-394.

[9] TÜBİSAD. E-Commerce in Turkey 2018 Market Size. 2018; Available from: https://www2.deloitte.com/content/dam/Deloitte/tr/Documents/tech nology-media-telecommunications/TUB\%C4\%B0SAD_2019_Ecomme rce_ENG.pdf.

[10] Potosky, D., The Internet knowledge (iKnow) measure. Computers in Human behavior, 2007. 23(6): p. 2760-2777.

[11] AlGhamdi, R., A. Nguyen, and V. Jones, A study of influential factors in the adoption and diffusion of B2C e-commerce. International Journal of Advanced Computer Science and Applications, 2013. 4(1): p. 89-94.

[12] Ono, H. and M. Zavodny, Digital inequality: A five country comparison using microdata. Social Science Research, 2007. 36(3): p. 1135-1155.

[13] Zhang, Y., Age, gender, and Internet attitudes among employees in the business world. Computers in Human Behavior, 2005. 21(1): p. 1-10.

[14] Yang, S.C. and C.-J. Tung, Comparison of Internet addicts and nonaddicts in Taiwanese high school. Computers in Human Behavior, 2007. 23(1): p. 79-96.

[15] Cheung, C.M., G.W. Chan, and M. Limayem, A critical review of online consumer behavior: Empirical research. Journal of Electronic Commerce in Organizations 2005. 3(4): p. 1-19.

[16] Lightner, N.J., What users want in e-commerce design: effects of age, education and income. Ergonomics, 2003. 46(1-3): p. 153-168.

[17] Sim, L.L. and S.M. Koi, Singapore's Internet shoppers and their impact on traditional shopping patterns. Journal of Retailing and Consumer Services, 2002. 9(2): p. 115-124.

[18] Teo, T.S. and V.K. Lim, Gender differences in internet usage and task preferences. Behaviour \& Information Technology, 2000. 19(4): p. 283295.

[19] Duch-Brown, N., et al., The impact of online sales on consumers and firms. Evidence from consumer electronics. International Journal of Industrial Organization, 2017. 52: p. 30-62.

[20] Pan, X., B.T. Ratchford, and V. Shankar, The evolution of price dispersion in internet retail markets, in Organizing the New Industrial Economy (Advances in Applied Microeconomics), M.R. Baye, Editor. 2003, Emerald Group Publishing Limited: Bingley. p. 85-105. 
[21] Li, B., et al., Key influencing factors of consumers' vegetable ecommerce adoption willingness, behavior, and willingness-behavior consistency in Beijing, China. British Food Journal, 2020.

[22] Crespo, A.H. and I.R. Del Bosque, The influence of the commercial features of the Internet on the adoption of e-commerce by consumers. Electronic Commerce Research and Applications, 2010. 9(6): p. 562-575.

[23] Castro-Lopez, A., J. Puente, and R. Vazquez-Casielles, Fuzzy inference suitability to determine the utilitarian quality of B2C websites. Applied Soft Computing, 2017. 57: p. 132-143.

[24] He, P., S. Zhang, and C. He, Impacts of logistics resource sharing on B2C E-commerce companies and customers. Electronic Commerce Research and Applications, 2019. 34: p. 100820.

[25] Kang, J.-W. and Y. Namkung, The information quality and source credibility matter in customers' evaluation toward food O2O commerce. International Journal of Hospitality Management, 2019. 78: p. 189-198.

[26] Shen, C.-w., M. Chen, and C.-c. Wang, Analyzing the trend of O2O commerce by bilingual text mining on social media. Computers in Human Behavior, 2019. 101: p. 474-483.

[27] Zhang, J., H. Chen, and X. Wu, Operation models in O2O supply chain when existing competitive service level. International Journal of u-and eService, Science and Technology, 2015. 8(9): p. 279-290.

[28] Jamaluddin, N., Adoption of e-commerce practices among the indian farmers, a survey of Trichy District in the State of Tamilnadu, India. Procedia Economics and Finance, 2013. 7: p. 140-149.

[29] Grandón, E.E., S.A. Nasco, and P.P. Mykytyn Jr, Comparing theories to explain e-commerce adoption. Journal of Business Research, 2011. 64(3): p. 292-298.

[30] Sin, K.Y., et al., Relative advantage and competitive pressure towards implementation of e-commerce: Overview of small and medium enterprises (SMEs). Procedia Economics and Finance, 2016. 35: p. 434443.

[31] Rana, N.P., et al., Exploring barriers of m-commerce adoption in SMEs in the UK: Developing a framework using ISM. International Journal of Information Management, 2019. 44: p. 141-153.

[32] Chau, N.T. and H. Deng, Critical determinants for mobile commerce adoption in Vietnamese SMEs: A conceptual framework. Procedia Computer Science, 2018. 138: p. 433-440.

[33] Yang, B. and D. Lester, Gender differences in e-commerce. Applied Economics, 2005. 37(18): p. 2077-2089.

[34] Baer, A.G. and C. Brown, Adoption of e-marketing by direct-market farms in the Northeastern United States. Journal of Food Distribution Research, 2007. 38(2): p. 1-11.

[35] Sismeiro, C. and R.E. Bucklin, Modeling purchase behavior at an ecommerce web site: A task-completion approach. Journal of Marketing Research, 2004. 41(3): p. 306-323.

[36] Solaymani, S., K. Sohaili, and E.A. Yazdinejad, Adoption and use of ecommerce in SMEs. Electronic Commerce Research, 2012. 12(3): p. 249263.

[37] Akman, I. and A. Mishra, Gender, age and income differences in internet usage among employees in organizations. Computers in Human Behavior, 2010. 26(3): p. 482-490.

[38] Alkan, Ö., H. Küçükoğlu, and G. Tutar, Modeling of the factors affecting e-commerce use in Turkey by categorical data analysis. International Journal of Advanced Computer Science and Applications, 2021. 12 (1): p. 95-105.

[39] Abar, H. and Ö. Alkan, What Factors Influence the Use of Electronic Commerce?: A Case in Turkey, in Handbook of Research on IT Applications for Strategic Competitive Advantage and Decision Making, E.C. Idemudia, Editor. 2020, IGI Global. p. 101-117.

[40] Durmuş, B., Y. Ulusu, and Ş. Erdem, Which dimensions affect private shopping e-customer loyalty? Procedia-Social and Behavioral Sciences, 2013. 99: p. 420-427.

[41] Zehir, C. and E. Narcıkara, E-service quality and e-recovery service quality: Effects on value perceptions and loyalty intentions. ProcediaSocial and Behavioral Sciences, 2016. 229: p. 427 - 443.

[42] TÜiK. Hanehalkı Bilișim Teknolojileri Kullanım Araștırması. 2019 24.11.2020; Available from: https://www.tuik.gov.tr/Kurumsal/Mikro_ Veri\#.
[43] Alkan, Ö., H. Abar, and A. Karaaslan, Evaluationof determinants on number of various information equipment at households in Turkey. International Journal of Business, Humanities and Technology, 2015. 5(5): p. 24-32.

[44] Alkan, Ö. and H. Abar, Determination of factors influencing tobacco consumption in Turkey using categorical data analyses1. Archives of Environmental \& Occupational Health, 2020. 75(1): p. 27-35.

[45] Alkan, Ö. and Ș. Ünver, Determinants of domestic physical violence against women in Turkey. Humanities \& Social Sciences Reviews, 2020. 8(6): p. 55-67.

[46] Alkan, Ö. and Ş. Ünver, Tobacco smoke exposure among women in Turkey and determinants. Journal of Substance Use, 2021.

[47] Cristóbal-Fransi, E., E. Martín-Fuentes, and N. Daries-Ramon, Behavioural analysis of subjects interacting with information technology: categorising the behaviour of e-consumers. International Journal of Services Technology and Management, 2015. 21(1-3): p. 163-182.

[48] Vicente, M., Determinants of C2C e-commerce: an empirical analysis of the use of online auction websites among Europeans. Applied Economics Letters, 2015. 22(12): p. 978-981.

[49] Smith, P., et al., The Internet: social and demographic impacts in Aotearoa New Zealand. Observatorio (OBS*) Journal, 2008. 6: p. 307330.

[50] Alqahtani, A.S., R.D. Goodwin, and D.B. de Vries, Cultural factors influencing e-commerce usability in Saudi Arabia. International Journal of Advanced and Applied Sciences, 2018. 5(6): p. 1-10.

[51] Hwang, W., H.-S. Jung, and G. Salvendy, Internationalisation of ecommerce: a comparison of online shopping preferences among Korean, Turkish and US populations. Behaviour \& Information Technology, 2006. 25(1): p. 3-18.

[52] Koyuncu, C. and D. Lien, E-commerce and consumer's purchasing behaviour. Applied Economics, 2003. 35(6): p. 721-726.

[53] Hashim, A., E.K. Ghani, and J. Said, Does consumers' demographic profile influence online shopping?: An examination using Fishbein's theory. Canadian Social Science, 2009. 5(6): p. 19-31.

[54] Escobar-Rodríguez, T., M.A. Grávalos-Gastaminza, and C. PérezCalañas, Facebook and the intention of purchasing tourism products: moderating effects of gender, age and marital status. Scandinavian Journal of Hospitality and Tourism, 2017. 17(2): p. 129-144.

[55] DeYoung, C.G. and I. Spence, Profiling information technology users: En route to dynamic personalization. Computers in Human Behavior, 2004. 20(1): p. 55-65.

[56] Donnermeyer, J.F. and C.A. Hollifield, Digital divide evidence in four rural towns. IT \& Society, 2003. 1(4): p. 107-117.

[57] Cullen, R., The digital divide: a global and national call to action. The electronic Library, 2003. 21(3): p. 247-257.

[58] Mills, B.F. and B.E. Whitacre, Understanding the Non - MetropolitanMetropolitan Digital Divide. Growth and Change, 2003. 34(2): p. 219243.

[59] Wilson, K.R., J.S. Wallin, and C. Reiser, Social stratification and the digital divide. Social Science Computer Review, 2003. 21(2): p. 133-143.

[60] Çera, G., et al., Financial capability and technology implications for online shopping. E\&M Economics and Management, 2020. 23(2): p. 156-172.

[61] Hubert, M., et al., Acceptance of smartphone - based mobile shopping: Mobile benefits, customer characteristics, perceived risks, and the impact of application context. Psychology \& Marketing, 2017. 34(2): p. 175-194.

[62] Pucci, T., et al., Does social media usage affect online purchasing intention for wine? The moderating role of subjective and objective knowledge. British Food Journal, 2019. 11(2): p. 275-288.

[63] Duroy, D., P. Gorse, and M. Lejoyeux, Characteristics of online compulsive buying in Parisian students. Addictive Behaviors, 2014. 39(12): p. 1827-1830.

[64] Akman, I., et al., E-Gov: A global perspective and an empirical assessment of citizens' attributes. Government Information Quarterly, 2005. 22(2): p. 239-257. 
[65] Hossein, K.M., et al., Factors Associated to Online Shopping at the BoP Community in Rural Bangladesh. International Journal of Advanced Computer Science and Applications, 2017. 8(10): p. 46-51.

[66] Stranahan, H. and D. Kosiel, E - tail spending patterns and the importance of online store familiarity. Internet Research, 2007. 17(4): p. 421-434.
[67] Leong, L.-Y., N.I. Jaafar, and S. Ainin, Understanding Facebook Commerce (F-Commerce) Actual Purchase from an Artificial Neural Network Perspective. Journal of Electronic Commerce Research, 2018. 19(1): p. 75-103. 